\title{
Reversible Binding of Ethylene and Propylene by Germylenes
}

\author{
Kelly L. Gullett, Ting Yi Lai, Chia-Yuan Chen, James C. Fettinger, and Philip P. Power* \\ Department of Chemistry, University of California, One Shields Avenue, Davis, California 95616, United States
}

Fax: +1-530-752-8995

E-mail: pppower@ucdaivs.edu

Table of Contents

S1 Table of Contents

S2 General Experimental Details

S3 Figure S1. ${ }^{1} \mathrm{H}$ NMR Spectrum of $\mathbf{1 a}\left(600 \mathrm{MHz}, \mathrm{C}_{7} \mathrm{D}_{8}, 273 \mathrm{~K}\right.$, ppm)

S4 Figure S2. ${ }^{1} \mathrm{H}$ NMR Spectrum of $\mathbf{1 b}\left(500 \mathrm{MHz}, \mathrm{C}_{7} \mathrm{D}_{8}, 298 \mathrm{~K}\right.$, ppm)

S5 Figure S3. ${ }^{13} \mathrm{C}$ NMR Spectrum of $\mathbf{1 b}\left(126 \mathrm{MHz}, \mathrm{C}_{6} \mathrm{D}_{6}, 298 \mathrm{~K}\right.$, ppm)

S6 Figure S4. ${ }^{1} \mathrm{H}$ NMR Spectrum of $\mathbf{1 c}\left(500 \mathrm{MHz}, \mathrm{C}_{7} \mathrm{D}_{8}, 248 \mathrm{~K}\right.$, , ppm)

S7 Variable temperature ${ }^{1} \mathrm{H}$ NMR spectroscopy and Van't Hoff analysis of 1a

S11 Variable temperature ${ }^{1} \mathrm{H}$ NMR spectroscopy and Van't Hoff analysis of $\mathbf{1 b}$

S15 Variable temperature ${ }^{1} \mathrm{H}$ NMR spectroscopy and Van't Hoff analysis of 1c

S19 Table S1. Selected X-ray Crystallographic Data for 1b

S20 Videos

S21 Reference 


\section{Experimental}

General Procedures. All operations were carried out under anaerobic and anhydrous conditions using modified Schlenk techniques. All solvents were dried over alumina columns and degassed prior to use. The ${ }^{1} \mathrm{H}$ and ${ }^{13} \mathrm{C}$ NMR spectroscopic data were collected on a Bruker $400 / 500 \mathrm{MHz}$ or a Varian $600 \mathrm{MHz}$ spectrometer. VT ${ }^{1} \mathrm{H}$ NMR data were recorded on a Bruker 500 instrument. $\mathrm{Ge}\left(\mathrm{Ar}^{\mathrm{Me}_{6}}\right)_{2}$ and $\mathrm{Ge}\left(\mathrm{Ar}^{\mathrm{iPr}_{4}}\right)_{2}$ were synthesized according to literature methods. ${ }^{1,2}$ Ethylene and propylene gas were dried via a $\mathrm{P}_{2} \mathrm{O}_{5} /$ Sieves drying column prior to use.

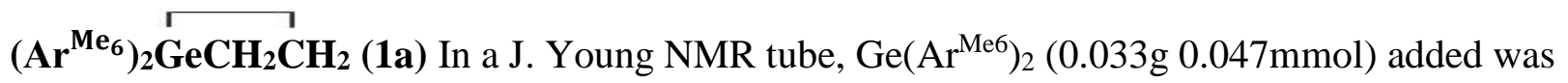
dissolved in d8-toluene. The solution is degassed twice and backfilled with ethylene. To ensure complete reaction the NMR sample, the NMR was left at RT for a day prior the NMR recording. ${ }^{1} \mathrm{H}$ NMR (500MHz, C7 $\left.\mathrm{D}_{8}, 248 \mathrm{~K}\right)$ : 0.53(s, 4H, CHGe), 1.76(s, 24H, o-Me), 2.24(s, 12H, p-Me), 6.5-7.5(14H aromatic $\mathrm{Hs})$

$\left(\mathrm{Ar}^{\mathrm{iPr}}{ }_{4}\right)_{2} \mathbf{G e C H}_{2} \mathrm{CH}_{2}(\mathbf{1 b})$ A rapidly stirred solution of $\mathrm{Ge}\left(\mathrm{Ar}^{\mathrm{iPr} 4}\right)_{2}(1.00 \mathrm{~g}, 1.15 \mathrm{mmol})$ in toluene ca. $30 \mathrm{~mL}$ was degassed 3 times then treated with ethylene gas. Storage of the solution at $-30^{\circ} \mathrm{C}$ afforded 1b. Yield $(0.3 \mathrm{~g}, 29 \%) \mathrm{Mp}: 112^{\circ} \mathrm{C}$ (turned blue), ${ }^{1} \mathrm{H}$ NMR $\left(500 \mathrm{MHz}, \mathrm{C}_{7} \mathrm{D}_{8}\right.$, 248K): $-0.04 / 0.51(\mathrm{t}, 4 \mathrm{H}, \mathrm{GeCH}), 0.66\left(\mathrm{~d}, 6 \mathrm{H}, \mathrm{CH}_{3} \mathrm{CH}\right), 0.97 / 0.98 / 1.64 / 1.25$ (d, 48H, $\left.\mathrm{CH}_{3} \mathrm{CH}\right)$, 1.66(m, $\left.4 \mathrm{H}, \mathrm{CH}_{3} \mathrm{CH}\right), 3.32\left(\mathrm{~m}, 4 \mathrm{H}, \mathrm{CH}_{3} \mathrm{CH}\right) .{ }^{13} \mathrm{C} \mathrm{NMR}\left(126 \mathrm{MHz}, \mathrm{C}_{6} \mathrm{D}_{6}, 298 \mathrm{~K}\right): 5.94,11.46$, 27.23, 28.39, 28.48, 29.75, 30.82, 30.97, 31.23, 31.64, 34.17, 34.89, 34.96, 36.74, 127.19, 127.6, $128.46,130.51,132.96,134.29,138.65,139.04,140.03,146.53,147.74,149.96,151.22,152.13$, $152.91,153.09,153.34$.

$\left.\left(\mathrm{Ar}^{\mathrm{iPr}}{ }_{4}\right)_{2} \mathbf{G e C H}_{2} \mathbf{C H C H}_{3}\right)$ (1c) In a J. Young NMR tube, Ge( $\left.\mathrm{Ar}^{\mathrm{iPr} 4}\right)_{2}(0.03 \mathrm{~g} \mathrm{mmol})$ added was dissolved in $\mathrm{d} 8$-toluene and the solution is degassed twice and backfilled with propylene. To ensure complete reaction the NMR sample, the NMR was left at RT for a day prior the NMR recording. However, the resulting broadening makes it difficult for NMR recording. The germirane signals are hidden in the isopropyl signals. ${ }^{1} \mathrm{H} \mathrm{NMR}\left(500 \mathrm{MHz}, \mathrm{C}_{7} \mathrm{D}_{8}, 248 \mathrm{~K}\right)$ : 0.38/0.54/0.73/0.99/1.21(d, 48Hs $\left.\mathrm{CH}_{3} \mathrm{CH}\right) 3.28\left(\mathrm{~m}, 4 \mathrm{H}, \mathrm{CH}_{3} \mathrm{CH}\right), 4.02\left(\mathrm{~m}, 4 \mathrm{H}, \mathrm{CH}_{3} \mathrm{CH}\right)$

$\left[\left(\mathrm{Ar}^{\mathrm{iPr}}{ }_{4}\right) \mathbf{G e}\left(\mathbf{C}_{2} \mathrm{H}_{5}\right)\right]_{2}(2)$ A rapidly stirred solution of $\mathrm{Ge}\left(\mathrm{Ar}^{\mathrm{iPr} 4}\right)_{2}(0.68 \mathrm{~g}, 0.78 \mathrm{mmol})$ in toluene ca. $30 \mathrm{~mL}$ was degassed 3 times then treated with ethylene gas. The solution was heated to $80^{\circ} \mathrm{C}$ for $12 \mathrm{~h}$. The solution is concentrated to $c a .20 \mathrm{~mL}$ and storage at $-30^{\circ} \mathrm{C}$ afforded 2 . Yield: $(0.125 \mathrm{~g}, 32 \%)$. 
Figure S1. ${ }^{1} \mathrm{H}$ NMR Spectrum of $1 \mathbf{a}\left(600 \mathrm{MHz}, \mathrm{C}_{7} \mathrm{D}_{8}, 273 \mathrm{~K}\right.$, ppm)

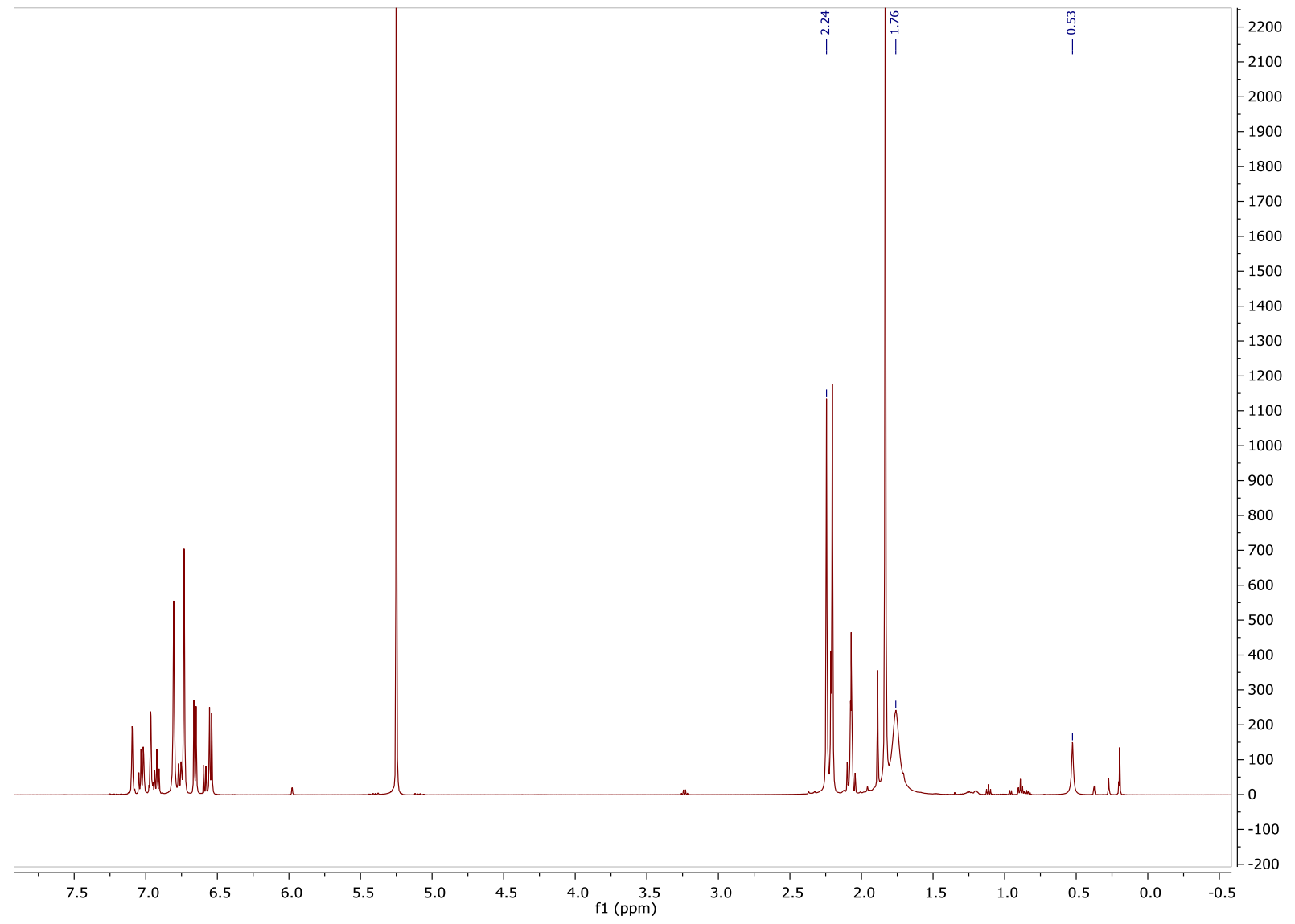


Figure S2. ${ }^{1} \mathrm{H}$ NMR Spectrum of $\mathbf{1 b}\left(500 \mathrm{MHz}, \mathrm{C}_{7} \mathrm{D}_{8}, 298 \mathrm{~K}, \mathrm{ppm}\right)$

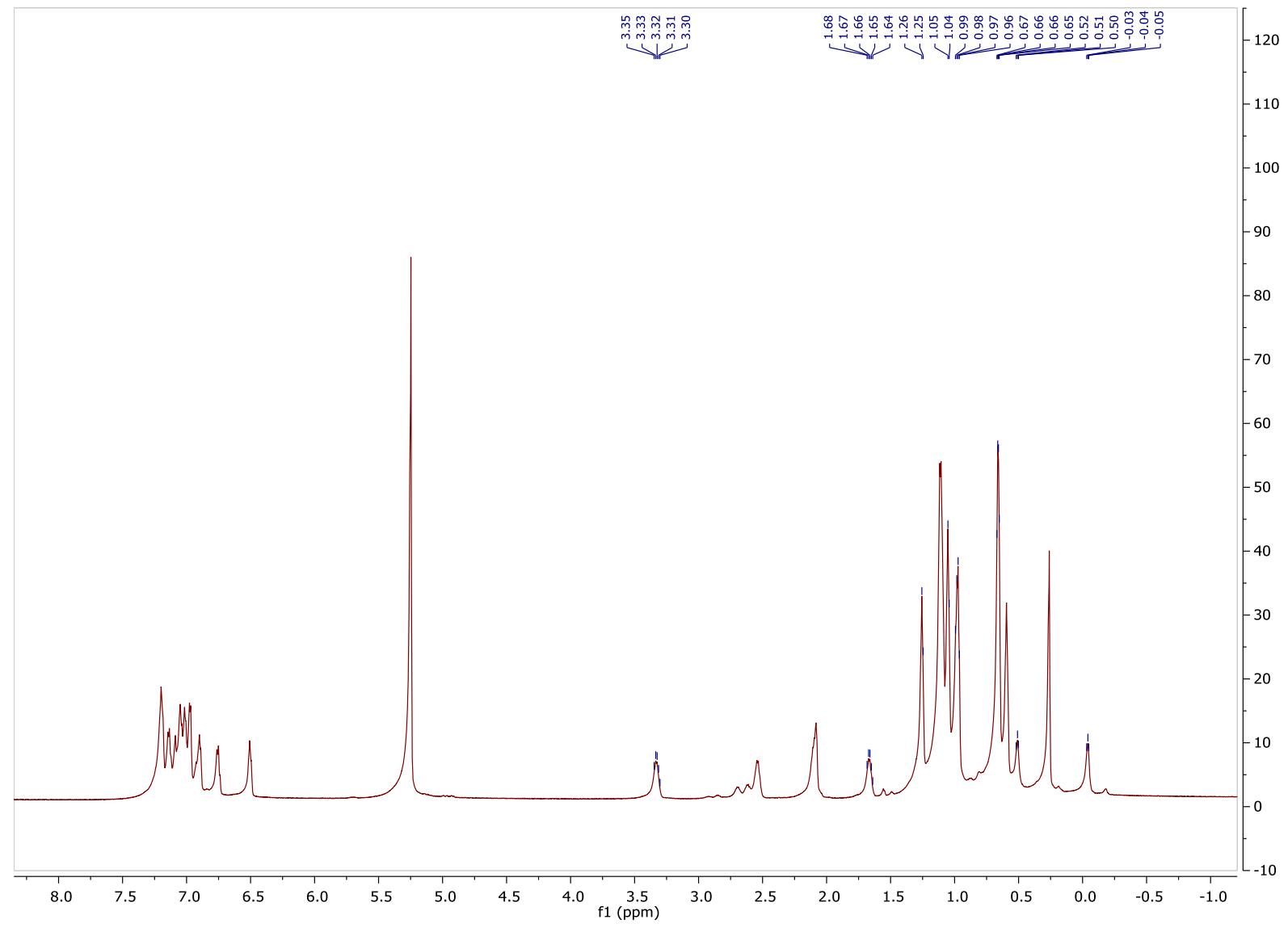


Figure S3. ${ }^{13} \mathrm{C}$ NMR Spectrum of $\mathbf{1 b}\left(126 \mathrm{MHz}, \mathrm{C}_{6} \mathrm{D}_{6}, 298 \mathrm{~K}\right.$, ppm)

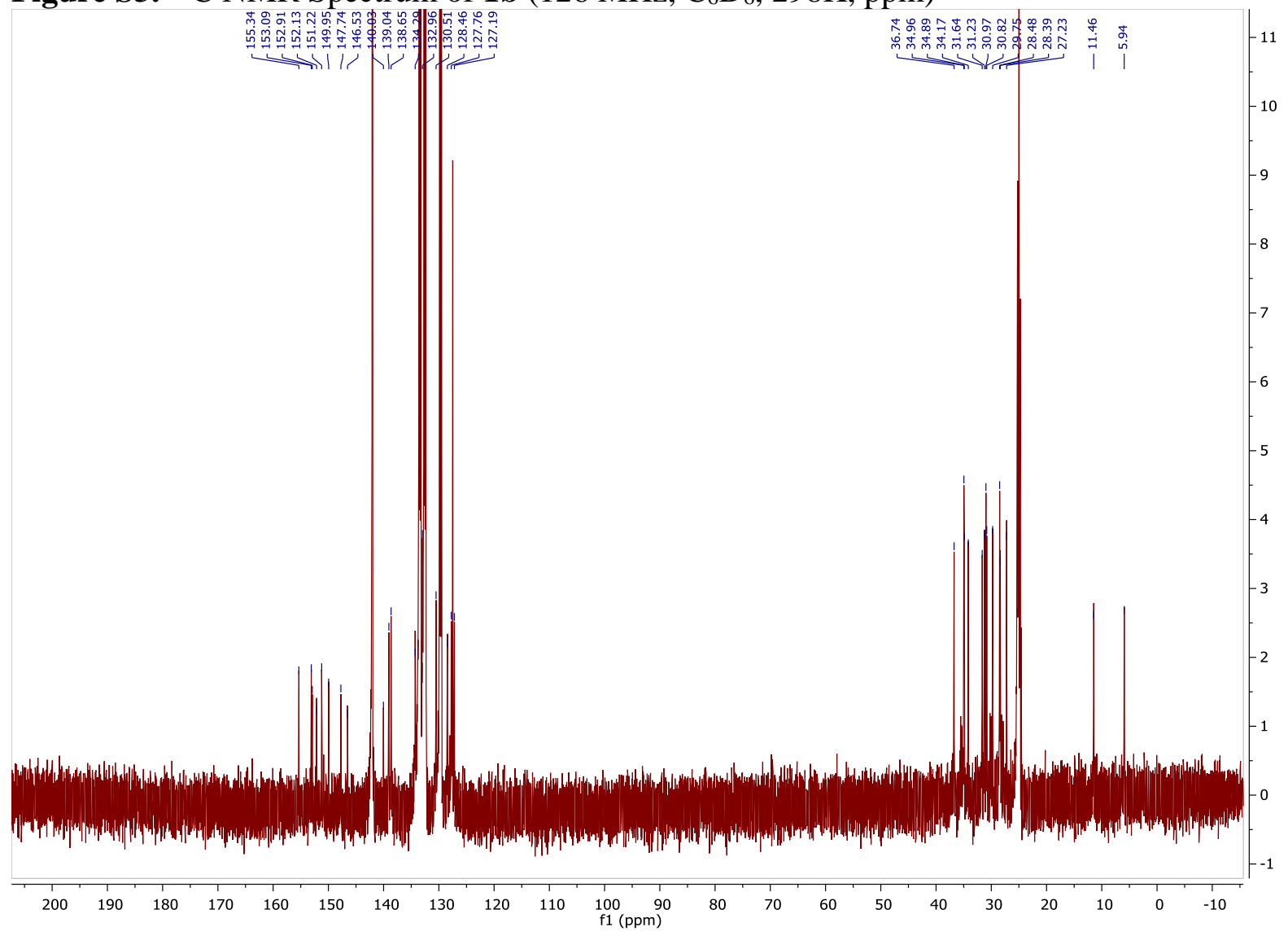


Figure S4. ${ }^{1} \mathrm{H}$ NMR Spectrum of $1 \mathrm{c}\left(500 \mathrm{MHz}, \mathrm{C}_{7} \mathrm{D}_{8}, 248 \mathrm{~K}, \mathrm{ppm}\right)$

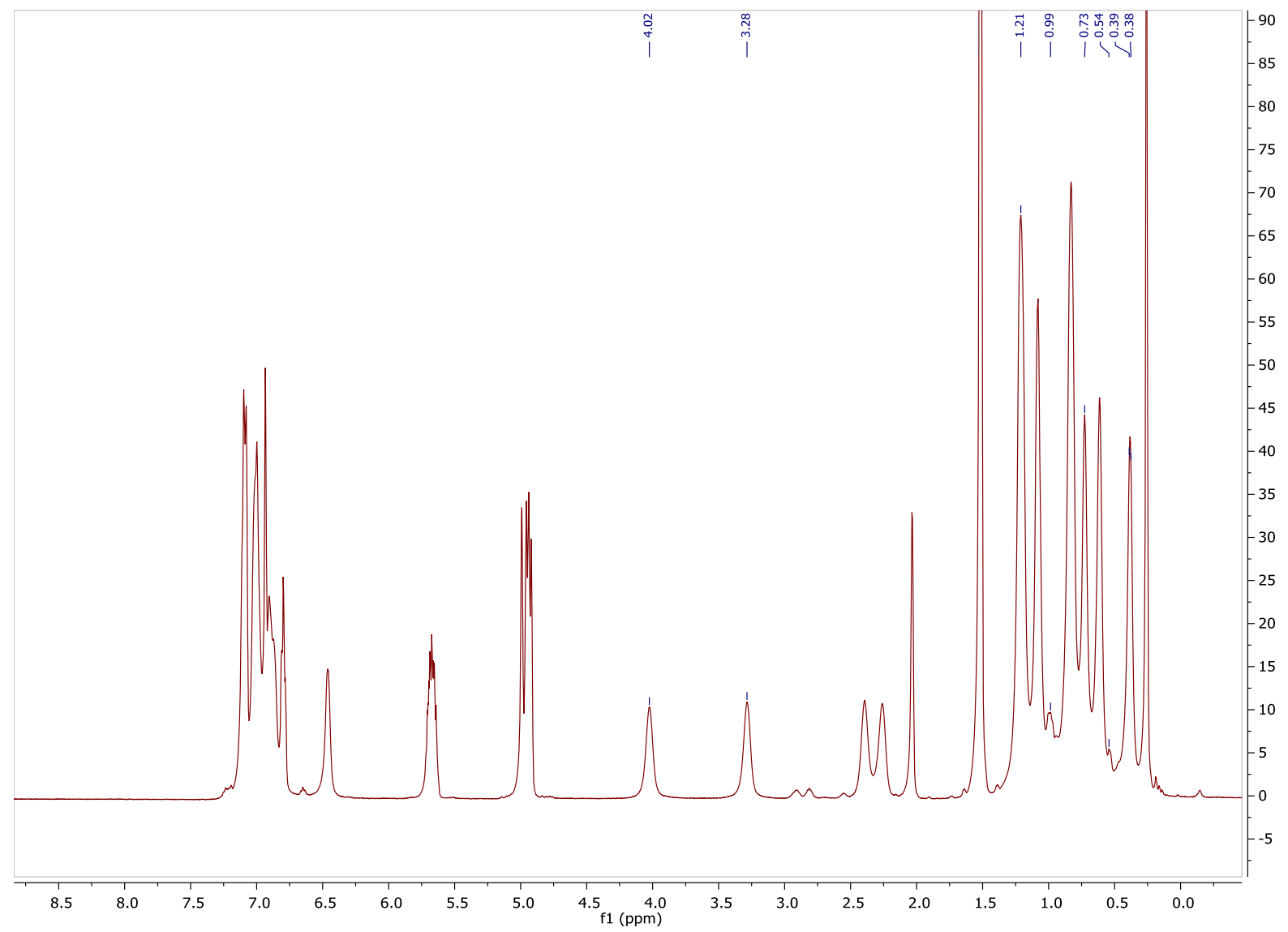


Variable temperature ${ }^{1} \mathrm{H}$ NMR spectroscopy and Van't Hoff analysis of $\mathbf{1 a}$

The integral atoms of the, o-Me group of $\mathrm{Ge}\left(\mathrm{Ar}^{\mathrm{Me}}\right)_{2}$, free ethylene and Me of the germirane in compound 1a were used for the determination of the equilibrium constant for the conversion of the germylene with ethylene to give the germirane.

The equilibrium constant was calculated according to equation 1.

$K_{e q}=\frac{[\text { Germirane }]}{[\text { Germylene }][\text { ethylene }]}($ eq1)

The Van't Hoff equation, equation 2, was used in order to determine $\Delta \mathrm{H}$ and $\Delta \mathrm{S}$ from the slope and the intercept of the plot of ln Keq against 1/T.

$\ln K_{e q}=-\frac{\Delta \mathrm{H}}{R}\left(\frac{1}{T}\right)+\frac{\Delta \mathrm{S}}{R}($ eq. 2$)$ 
Figure S5. ${ }^{1} \mathrm{H}$ NMR spectrum for 1a at various temperatures from 257 to $298 \mathrm{~K}(500 \mathrm{MHz}$, $\left.\mathrm{C}_{7} \mathrm{D}_{8}\right)$

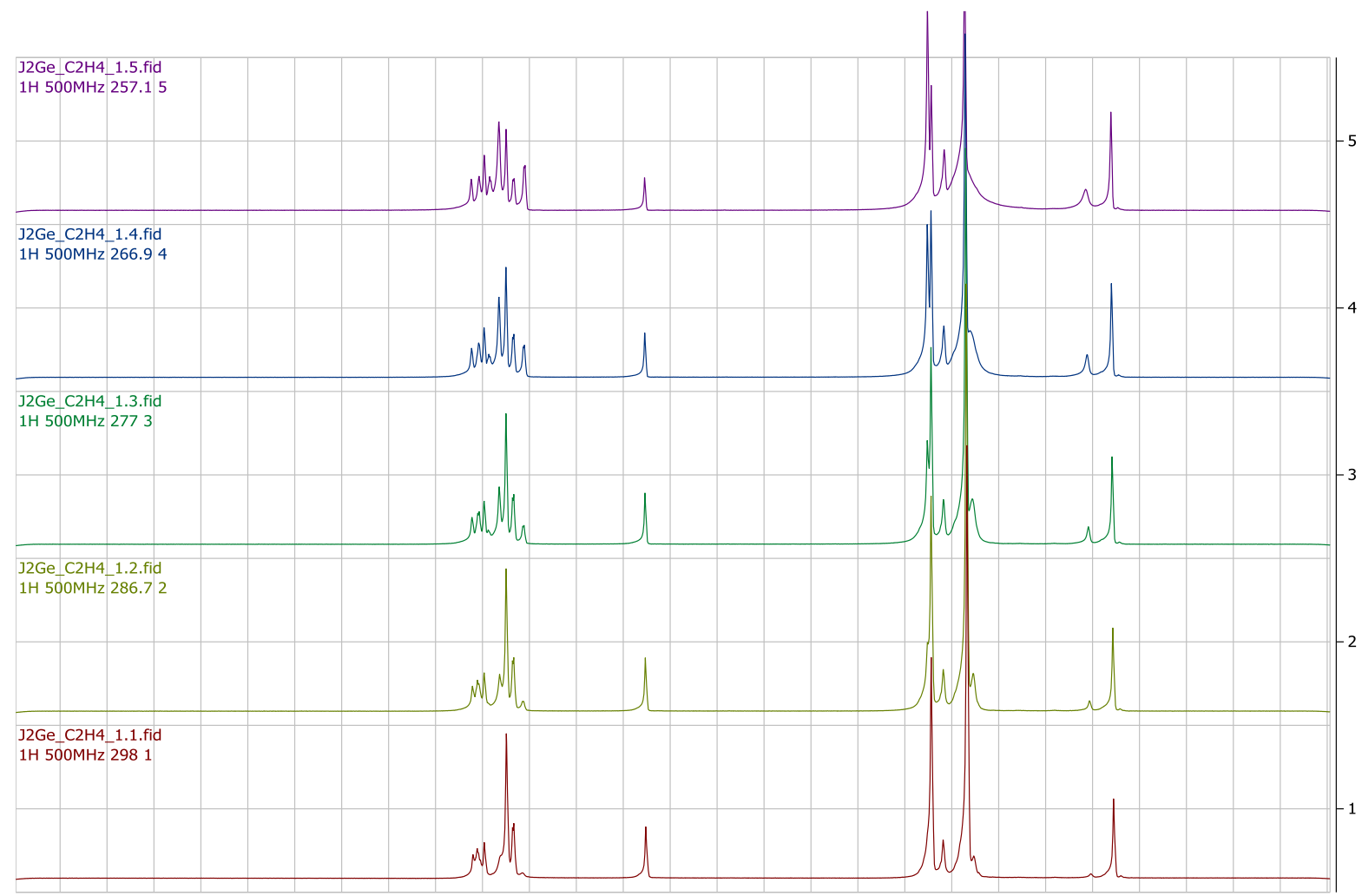

$\begin{array}{llllllllllllllllllllllllllllllllllll}11.5 & 11.0 & 10.5 & 10.0 & 9.5 & 9.0 & 8.5 & 8.0 & 7.5 & 7.0 & 6.5 & 6.0 & 5.5 & 5.0 & 4.5 & 4.0 & 3.5 & 3.0 & 2.5 & 2.0 & 1.5 & 1.0 & 0.5 & 0.0 & -0.5 & -1.0 & -1.5 & -2.0\end{array}$ 


$\begin{array}{ccccc}\mathbf{T} & \mathrm{Ge}\left(\mathrm{Ar}^{\mathrm{Me}}\right)_{\mathbf{2}} & \text { Ethylene } & \text { complex } & \text { Intensity } \\ \mathbf{2 9 8} & 249.4 & 26.76 & 4 & \\ \mathbf{2 8 6} & 245.64 & 27.41 & 6.02 & \\ \mathbf{2 7 8} & 239.72 & 25.67 & 12.68 & \\ \mathbf{2 6 8} & 228.85 & 24.28 & 23.63 & \end{array}$

$\begin{array}{ccccc}\mathbf{T} & \mathrm{Ge}\left(\mathrm{Ar}^{\mathrm{Me} 6}\right)_{2} & \text { Ethylene } & \text { complex } & \begin{array}{c}\text { Scale to number of } \\ \text { Hydrogens }\end{array} \\ \mathbf{2 9 8} & 10.39166667 & 6.69 & 1 & \\ \mathbf{2 8 8} & 10.235 & 6.8525 & 1.505 & \\ \mathbf{2 7 8} & 9.988333333 & 6.4175 & 3.17 & \\ \mathbf{2 6 8} & 9.535416667 & 6.07 & 5.9075 & \end{array}$

$\begin{array}{ccccc}\mathbf{T} & \mathrm{Ge}\left(\mathrm{Ar}^{\mathrm{Me}}\right)_{2} & \text { Ethylene } & \text { complex } & \mathrm{mol} \\ \mathbf{2 9 8} & 0.000228617 & 0.00014718 & 0.000022 & \\ \mathbf{2 8 8} & 0.00022517 & 0.000150755 & 0.00003311 & \\ \mathbf{2 7 8} & 0.000219743 & 0.000141185 & 0.00006974 & \\ \mathbf{2 6 8} & 0.000209779 & 0.00013354 & 0.000129965 & \end{array}$

$\begin{array}{ccccc}\mathbf{T} & \mathrm{Ge}\left(\mathrm{Ar}^{\mathrm{Me} 6}\right)_{2} & \text { Ethylene } & \text { complex } & \begin{array}{c}\text { Concentration } \\ \text { Volume }\end{array} \\ \mathbf{2 9 8} & 0.457233333 & 0.29436 & 0.044 & 5.00 \mathrm{E}-04 \\ \mathbf{2 8 8} & 0.45034 & 0.30151 & 0.06622 & \\ \mathbf{2 7 8} & 0.439486667 & 0.28237 & 0.13948 & \\ \mathbf{2 6 8} & 0.419558333 & 0.26708 & 0.25993 & \end{array}$


Van't Hoff analysis of Figure S5.

$\begin{array}{cccc}\mathbf{T} & \text { Keq } & \text { InK } & \mathbf{1 / T} \\ \mathbf{2 9 8} & 0.326 & -1.118 & 0.0033 \\ \mathbf{2 8 8} & 0.488 & -0.718 & 0.0035 \\ \mathbf{2 7 8} & 1.124 & 0.1168 & 0.00362 \\ \mathbf{2 6 8} & 2.319 & 0.841 & 0.0037\end{array}$

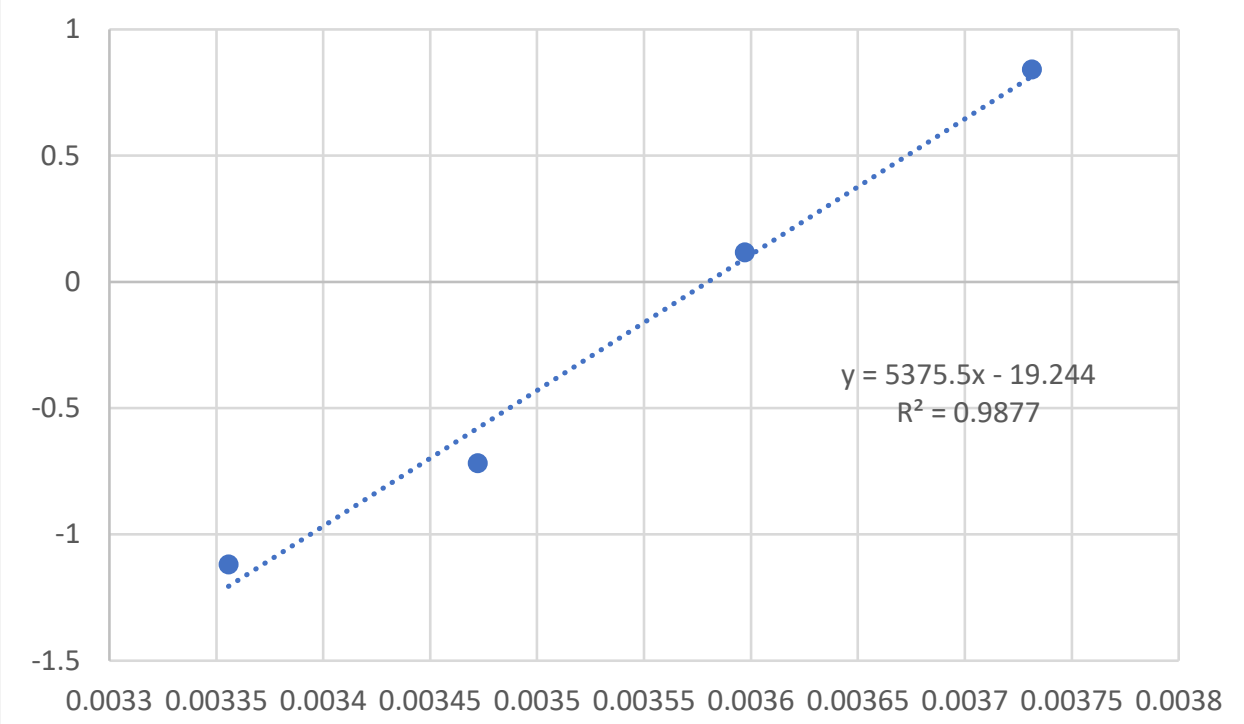

$\Delta \mathrm{H}_{\mathrm{ass}}=-44.69 \mathrm{~kJ} \mathrm{~mol}^{-1}$

$\Delta \mathrm{S}_{\mathrm{ass}}=-159.82 \mathrm{~J} \mathrm{~K}^{-1} \mathrm{~mol}^{-1}$

$\Delta \mathrm{G}_{\mathrm{ass}}(298 \mathrm{~K})=-6.3 \mathrm{~kJ} \mathrm{~mol}^{-1}$

Estimate of Error:

The uncertainty in the integration was estimated to be 5\%. The VT apparatus indicated an uncertainty in the temperature of $1{ }^{\circ} \mathrm{C}$. The concentration is accurate ca. $5 \%$ and $2 \%$ for the germylene. 
Variable temperature ${ }^{1} \mathrm{H}$ NMR spectroscopy and Van't Hoff analysis of $\mathbf{1 b}$

The integral atoms of the, iPr group of $\mathrm{Ge}\left(\mathrm{Ar}^{\mathrm{iPr} 4}\right)_{2}$, free ethylene and Me of the germirane in compound $\mathbf{1 b}$ were used for the determination of the equilibrium constant for the conversion of the germylene with ethylene to give the germirane. 
Figure S6. ${ }^{1} \mathrm{H}$ NMR spectrum for $\mathbf{1 b}$ at various temperatures from 258 to $298 \mathrm{~K}(500 \mathrm{MHz}$, $\left.\mathrm{C}_{7} \mathrm{D}_{8}\right)$
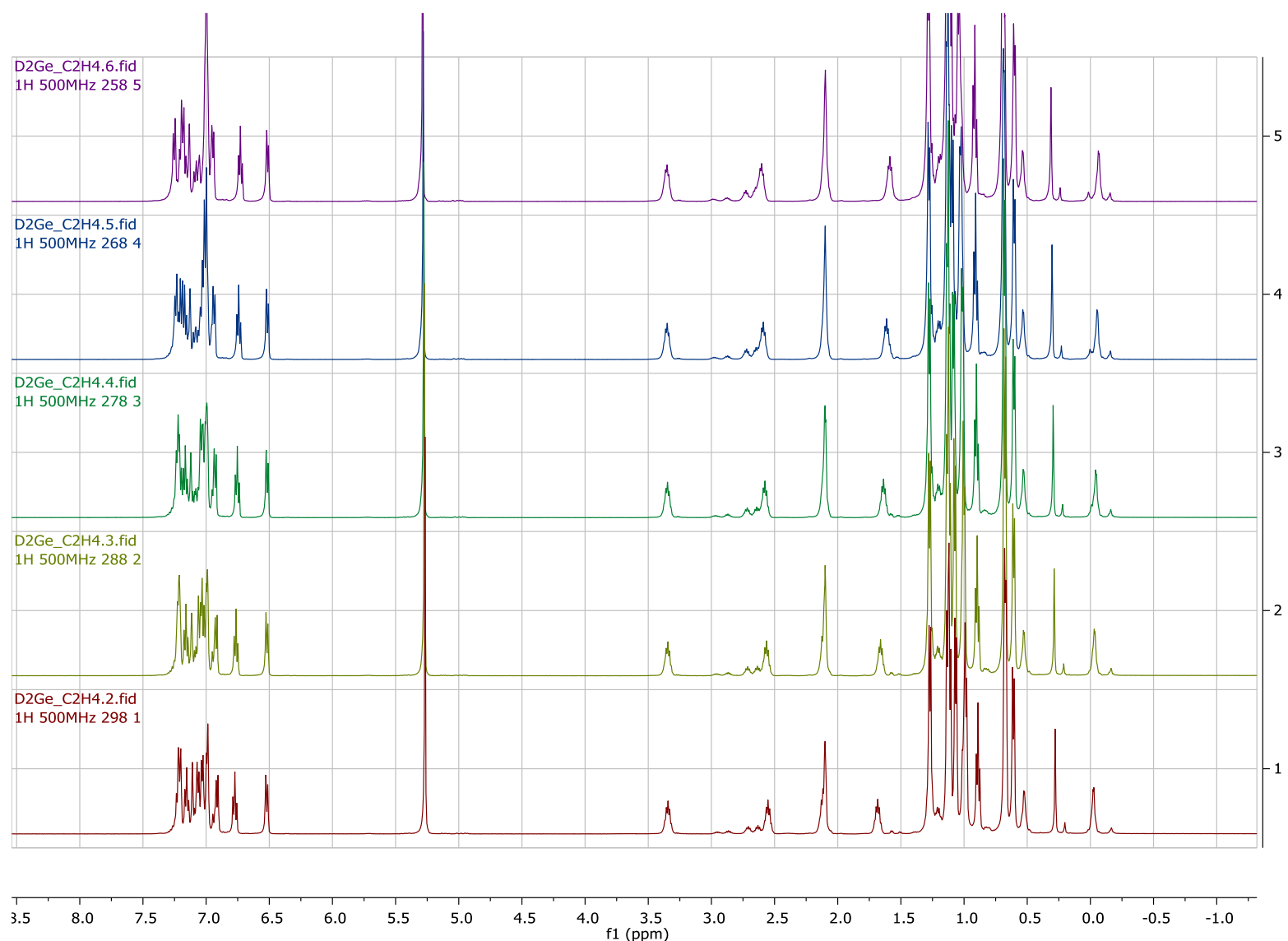


\begin{tabular}{|c|c|c|c|c|}
\hline $\mathbf{T}$ & $\mathrm{Ge}\left(\mathrm{Ar}^{\mathrm{iPr} 4}\right)_{2}$ & Ethylene & complex & \\
\hline 298 & 3.97 & 9.69 & 4 & Intensity \\
\hline 288 & 3.85 & 10.19 & 4.1 & \\
\hline 278 & 3.77 & 10.53 & 4.2 & \\
\hline 268 & 3.68 & 10.81 & 4.4 & \\
\hline 258 & 3.51 & 11.69 & 4.61 & \\
\hline $\mathbf{T}$ & $\mathrm{Ge}\left(\operatorname{Ar}^{\mathrm{iPr} 4}\right)_{2}$ & Ethylene & complex & Scale to number of Hydrogens \\
\hline 298 & 0.49625 & 2.4225 & 1 & \\
\hline 288 & 0.48125 & 2.5475 & 1.025 & \\
\hline 278 & 0.47125 & 2.6325 & 1.05 & \\
\hline 268 & 0.46 & 2.7025 & 1.1 & \\
\hline 258 & 0.43875 & 2.9225 & 1.1525 & \\
\hline $\mathbf{T}$ & $\mathrm{Ge}\left(\operatorname{Ar}^{\mathrm{iPr} 4}\right)_{2}$ & Ethylene & complex & \\
\hline 298 & $1.09175 \mathrm{E}-05$ & 0.000053295 & 0.000022 & mol \\
\hline 288 & $1.05875 \mathrm{E}-05$ & 0.000056045 & 0.00002255 & \\
\hline 278 & $1.03675 \mathrm{E}-05$ & 0.000057915 & 0.0000231 & \\
\hline 268 & 0.00001012 & 0.000059455 & 0.0000242 & \\
\hline 258 & $9.6525 \mathrm{E}-06$ & 0.000064295 & 0.000025355 & \\
\hline $\mathbf{T}$ & $\mathrm{Ge}\left(\operatorname{Ar}^{\mathrm{iPr} 4}\right)_{2}$ & Ethylene & complex & Concentration Volume \\
\hline 298 & 0.021835 & 0.10659 & 0.044 & 5.00E-04 \\
\hline 288 & 0.021175 & 0.11209 & 0.0451 & \\
\hline 278 & 0.020735 & 0.11583 & 0.0462 & \\
\hline 268 & 0.02024 & 0.11891 & 0.0484 & \\
\hline 258 & 0.019305 & 0.12859 & 0.05071 & \\
\hline
\end{tabular}


Van't Hoff analysis of Figure S6.

$\begin{array}{cccc}\mathbf{T} & \text { Keq } & \text { InK } & \mathbf{1 / T} \\ \mathbf{2 9 8} & 18.9 & 2.93 & 0.00335 \\ \mathbf{2 8 8} & 19.0 & 2.94 & 0.00347 \\ \mathbf{2 7 8} & 19.23 & 2.956 & 0.0036 \\ \mathbf{2 6 8} & 20.11 & 3.0 & 0.0037 \\ \mathbf{2 5 8} & 20.42 & 3.01 & 0.0039\end{array}$

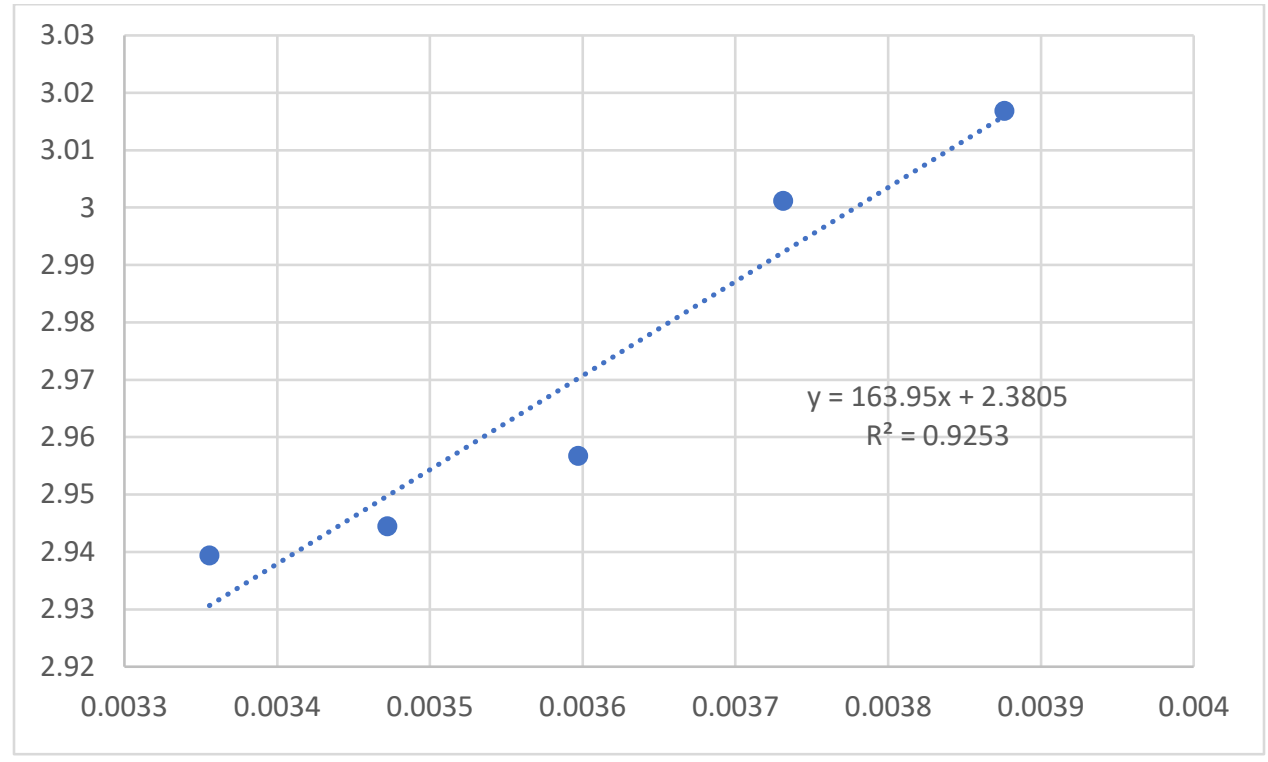

$\Delta \mathrm{H}_{\mathrm{ass}}=-1.36 \mathrm{~kJ} \mathrm{~mol}^{-1}$

$\Delta \mathrm{S}_{\text {ass }}=19.78 \mathrm{~J} \mathrm{~K}^{-1} \mathrm{~mol}^{-1}$

$\Delta \mathrm{G}_{\mathrm{ass}}(298 \mathrm{~K})=-7.25 \mathrm{~kJ} \mathrm{~mol}^{-1}$

Estimate of Error:

The uncertainty in the integration was estimated to be $10 \%$ due to broadening. The VT apparatus indicated an uncertainty in the temperature of $1{ }^{\circ} \mathrm{C}$. The concentration is accurate ca. $5 \%$ and $2 \%$ for the germylene. 
Variable temperature ${ }^{1} \mathrm{H}$ NMR spectroscopy and Van’t Hoff analysis of 1c

The integral atoms of the, iPr group of $\mathrm{Ge}\left(\mathrm{Ar}^{\mathrm{iPr} 4}\right)_{2}$, free ethylene and iPr of the germirane in compound 1c were used for the determination of the equilibrium constant for the conversion of the germylene with ethylene to give the germirane. 
Figure S7. ${ }^{1} \mathrm{H}$ NMR spectrum for 1c at various temperatures from 218 to $268 \mathrm{~K}(500 \mathrm{MHz}$, $\left.\mathrm{C}_{7} \mathrm{D}_{8}\right)$
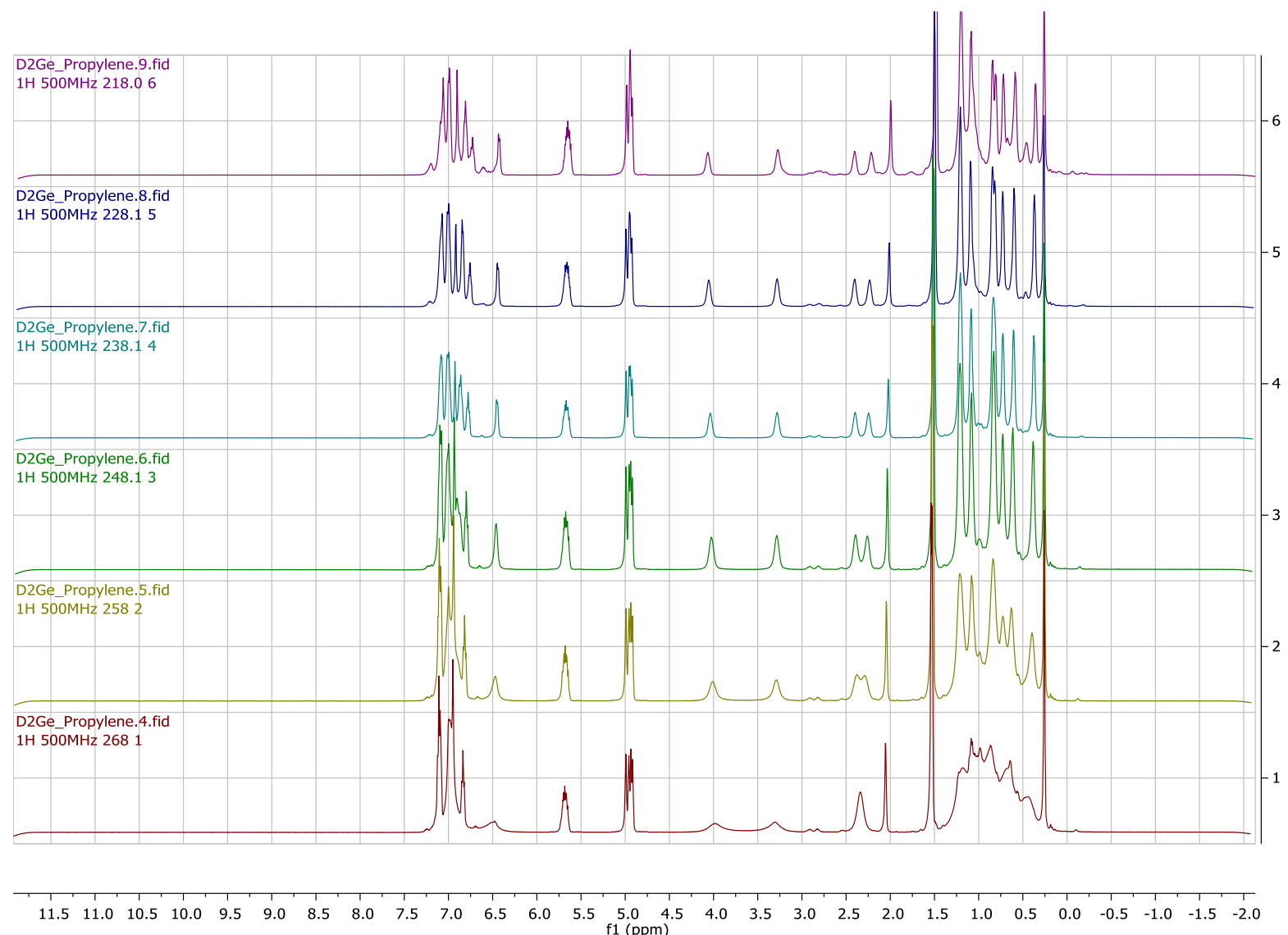


\begin{tabular}{|c|c|c|c|c|}
\hline$T$ & $\mathrm{Ge}\left(A r^{\mathrm{iPr} 4}\right)_{2}$ & Propylene & complex & \\
\hline 268 & 10.3 & 7.04 & 4 & Intensity \\
\hline 258 & 10.1 & 7.43 & 4.3 & \\
\hline 248 & 9.92 & 8.2 & 4.68 & \\
\hline 238 & 9.5 & 8.64 & 4.87 & \\
\hline 228 & 9.02 & 8.93 & 4.99 & \\
\hline $\mathbf{T}$ & $\mathrm{Ge}\left(\operatorname{Ar}^{\mathrm{iPr} 4}\right)_{2}$ & Propylene & complex & $\begin{array}{c}\text { Scale to number of } \\
\text { Hydrogens }\end{array}$ \\
\hline 268 & 1.2875 & 7.04 & 1 & \\
\hline 258 & 1.2625 & 7.43 & 1.075 & \\
\hline 248 & 1.24 & 8.2 & 1.17 & \\
\hline 238 & 1.1875 & 8.64 & 1.2175 & \\
\hline 228 & 1.1275 & 8.93 & 1.2475 & \\
\hline$T$ & $\mathrm{Ge}\left(\mathrm{Ar}^{\mathrm{iPr} 4}\right)_{2}$ & Propylene & complex & \\
\hline 268 & 0.000028325 & 0.00015488 & 0.000022 & $\mathrm{~mol}$ \\
\hline 258 & 0.000027775 & 0.00016346 & 0.00002365 & \\
\hline 248 & 0.00002728 & 0.0001804 & 0.00002574 & \\
\hline 238 & 0.000026125 & 0.00019008 & 0.000026785 & \\
\hline 228 & 0.000024805 & 0.00019646 & 0.000027445 & \\
\hline$T$ & $\mathrm{Ge}\left(\operatorname{Ar}^{\mathrm{iPr} 4}\right)_{2}$ & Propylene & complex & $\begin{array}{c}\text { Concentration } \\
\text { Volume }\end{array}$ \\
\hline 268 & 0.05665 & 0.30976 & 0.044 & $5.00 \mathrm{E}-04$ \\
\hline 258 & 0.05555 & 0.32692 & 0.0473 & \\
\hline 248 & 0.05456 & 0.3608 & 0.05148 & \\
\hline 238 & 0.05225 & 0.38016 & 0.05357 & \\
\hline 228 & 0.04961 & 0.39292 & 0.05489 & \\
\hline
\end{tabular}


Van't Hoff analysis of Figure S7

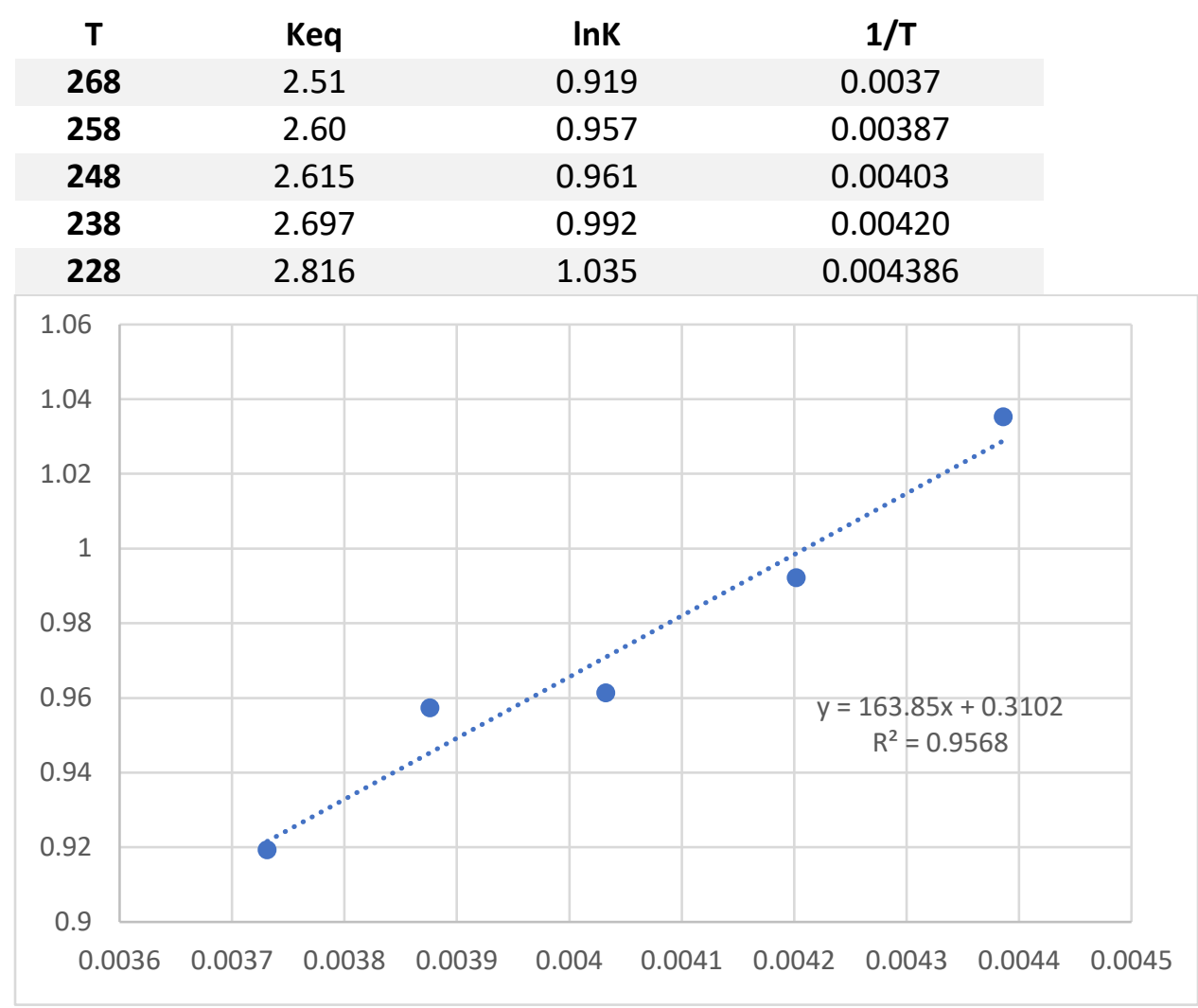

$\Delta \mathrm{H}_{\mathrm{ass}}=-1.362 \mathrm{~kJ} \mathrm{~mol}^{-1}$

$\Delta \mathrm{S}_{\mathrm{ass}}=2.579 \mathrm{~J} \mathrm{~K}^{-1} \mathrm{~mol}^{-1}$

$\Delta \mathrm{G}_{\mathrm{ass}}(298 \mathrm{~K})=-2.1 \mathrm{~kJ} \mathrm{~mol}^{-1}$

Estimate of Error:

The uncertainty in the integration was estimated to be $10 \%$ due to broadening. The VT apparatus indicated an uncertainty in the temperature of $1{ }^{\circ} \mathrm{C}$. The concentration is accurate ca. $5 \%$ and $2 \%$ for the germylene. 
Table S1. Selected X-ray Crystallographic Data for $\mathbf{1 b}$.

\begin{tabular}{|c|c|}
\hline Compound & $\mathbf{1 b}$ \\
\hline Formula weight, gmol $^{-1}$ & C145 H180 Ge2 \\
\hline$T(\mathrm{~K}) / l(\AA)$ & $90(2) \mathrm{K} / 0.71073 \AA$ \\
\hline Crystal system & Triclinic \\
\hline Space group / Z & $\mathrm{P}-1$ \\
\hline$a, \AA$ & $12.408(2) \AA$ \\
\hline$b, \AA$ & $19.126(4) \AA$ \\
\hline$c, \AA$ & $26.398(5) \AA$ \\
\hline$\alpha,^{\circ}$ & $93.954(4)^{\circ}$ \\
\hline$\beta,{ }^{\circ}$ & $91.913(4)^{\circ}$ \\
\hline$\gamma,{ }^{\circ}$ & $108.740(3)^{\circ}$ \\
\hline $\mathrm{V}, \AA^{3}$ & $5908.3(19) \AA^{3}$ \\
\hline$\rho, \mathrm{mg} \mathrm{m}^{-3}$ & $1.162 \mathrm{Mg} / \mathrm{m}^{3}$ \\
\hline Abs. coeff., $\mathrm{mm}^{-1}$ & $0.560 \mathrm{~mm}^{-1}$ \\
\hline $\mathrm{F}(000)$ & 2228 \\
\hline Crystal size, $\mathrm{mm}^{3}$ & $0.804 \times 0.678 \times 0.670 \mathrm{~mm}^{3}$ \\
\hline$\theta$ range $^{\circ}$ & 1.859 to $25.416^{\circ}$. \\
\hline Reflns collected & 19267 \\
\hline Ind. reflns & 19267 \\
\hline Obs. reflns $[I>2 \sigma(I)]$ & 18482 \\
\hline Completeness to $2 \theta$ & $87.3 \%$ \\
\hline Goodness-of-fit $\mathrm{F}^{2}$ & 1.133 \\
\hline Final $R[I>2 \sigma(I)]$ & $\begin{array}{l}\mathrm{R} 1=0.0664 \\
\mathrm{wR} 2=0.1863\end{array}$ \\
\hline$R$ (all data) & $\begin{array}{l}\mathrm{R} 1=0.0684 \\
\mathrm{wR} 2=0.1875\end{array}$ \\
\hline
\end{tabular}

Completeness statistics refer to single and composite reflections containing twin component 1 only. 
Videos:

https://youtu.be/a1wrfESMbWQ 


\section{Reference:}

1. Simons, R.S.; Pu, L.; Olmstead, M.M.; and Power, P.P.” Synthesis and Characterization of the Monomeric Diaryls $\mathrm{M}\left\{\mathrm{C}_{6} \mathrm{H}_{3}-2,6-\mathrm{Mes}_{2}\right\}_{2}\left(\mathrm{M}=\mathrm{Ge}, \mathrm{Sn}\right.$, or Pb; Mes = 2,4,6- $\left.\mathrm{Me}_{3} \mathrm{C}_{6} \mathrm{H}_{2}-\right)$ and Dimeric Aryl-Metal Chlorides $\left[\mathrm{M}(\mathrm{Cl})\left\{\mathrm{C}_{6} \mathrm{H}_{3}-2,6-\mathrm{Mes}_{2}\right\}\right]_{2}(\mathrm{M}=\mathrm{Ge}$ or $\mathrm{Sn}) "$ Organometallics, 1997, 16, 1920-1925.

2. Spikes, G.H.; Peng, Y.; Fettinger, J.C.; and Power, P.P. "Synthesis and Characterization of the Monomeric Sterically Encumbered Diaryls E $\left\{\mathrm{C}_{6} \mathrm{H}_{3}-2,6-\left(\mathrm{C}_{6} \mathrm{H} 3-2,6-i \mathrm{Pr}_{2}\right)_{2}\right\}_{2}(\mathrm{E}=\mathrm{Ge}, \mathrm{Sn}$, or Pb" Z. Anorg. Allg. Chem. 2006, 632, 1005-1010 